621.317



ст тті проведено н ліз принципів розробки вірту льних з собів вимірюв ння і пропонується $n$ кет комп'ютерних моделей-трен жерів н основі вірту льних вимірюв льних прил дів. ок $з$ н сфер використ ння вірту льних вимірюв льних прил дів.

лючові слов : вірту льні з собі вимірюв ння, прогр мне середовище, комп'ютерн модель.

ост новк проблеми. н ліз суч сного ст ну вимірюв льної техніки т тенденцій іï под льшого розвитку свідчить про те, що поряд з розробкою т $\quad$ удоскон ленням тр диційних вимірюв льних прил дів все більшого зн чення н був є новий н прям - розробк т к зв них вірту льних прил дів вимірюв ння. ьому сприяє, по-перше, зн чний прогрес в розвитку з собів електронно-обчислюв льної техніки ( ), коли персон льні комп'ютери ( ) пр ктично ст ли звичним, ч сто і необхідним інструментом інженерів, н уковців, викл д чів; по-друге, п рк з собів вимірюв ння ( ) поповнюється т відновляється не т кими темп ми, як потребують суч сні вимоги; по-третє, порушення інтегр ційних зв'язків з кр їн ми колишнього зн чно ускл днює процес розробки, головне виробництв суч сних тощо. се це потребує пошуку льтерн тивних шляхів вдоскон лення п рку, н прикл д, у вигляді розробки т створення вірту льних вимірюв льних прил дів.

н ліз публік цій. роведений н ліз літер тури [1-5] пок з в, що існує декільк принципів побудови вірту льних . к, н прикл д, т кі фірми, як “LeGroy", “Tektronix", "Hewlett-Packard" ф ктично ре лізують концепцію комп’ютеріз ції , тобто концепцію вбудови

бо мікропроцесорного контролер ( ) в корпус прил ду. рикл ди ре ліз ції т кого підходу $\epsilon$ i серед вітчизняних : вольтметр 7-34, ч стотомір 3-64, в які вбудов ні . дним 3 н йв жливіших недоліків т ких прил дів є досить обмежені можливості вбудов них з собів ільш перспективним є підхід, в основу якого покл дений принцип з'єдн ння 3 пл тою збир ння д них, основними елемент ми якої $\epsilon$ : д тчик, н логово-цифровий перетворюв ч $\mathrm{i}$ перетворюв ч код-код. ожливо включення до скл ду пл ти збир ння д них мікропроцесорного контролер , який буде виконув ти функції упр вління, синхроніз ції т підтримки прогр много з безпечення.

ироковідомий п кет "LabWiEW" в принципі ре лізує розглянутий підхід до побудови вірту льних , ле м є суттєві недоліки в пл ні візу ліз ції процесу вимірюв нь т відобр женні його результ тів. пр в в тому, що прогр мне середовище "LabWiEW" хоч і дозволяє відобр зити передню п нель обр ного , ле не д є можливості опер тору вносити зміни, корегув ти його зовнішній вигляд і функціон льні можливості.

ким чином, кту льності н був є пит ння, пов'яз не з візу ліз цією процесу вимірюв нь, тобто розробки вірту льного , зовнішній вигляд т функціон льні можливості якого можн було б корегув ти як під ч с розробки, т к і в процесі роботи.

ет ст тті. Н ст ття присвячен одному 3 можливих підходів до розробки вірту льних вимірюв льних прил дів - розробці п кету комп'ютерних моделей-трен жерів.

$\begin{array}{llll}\text { сновн ч стин . } & \text { н ліз існуючих }\end{array}$ інтер ктивних прогр мних середовищ пок 3 в, що з д ч візу ліз ції може бути вирішен 3 допомогою т ких п кетів прогр много з безпечення, як C+, ++, Visual Basic тощо, які м ють пр ктично одн кові можливості і 
відрізняються покл деною в основу форм лізов ною мовою прогр мув ння. бр ння Visual Basic в якості інтер ктивного прогр много середовищ для побудови вірту льних вимірюв льних прил дів виклик но н с мперед простотою, доступністю i високим рівнем форм лізов ності мови прогр мув ння Basic, як покл ден в основу інтер ктивного прогр много середовищ Visual Basic.

е одним не менш в жливим н прямом використ ння вірту льних $€$ побудов н їх основі комп'ютерних моделей-трен жерів 3 метою удоскон лення т підвищення н очності н вч льного процесу під ч с викл д ння н с мперед “прил дових" дисциплін. кту льність цього н пряму поляг $є$ в тому, що, по-перше, скл д шт тних , який є в н явності і який потрібен для з безпечення якісного проведення н вч льного процесу, як пр вило, є обмеженим, ч сто потребує ремонту, відновлення бо з міни, тому зн чення комп'ютерних трен жерів у т ких вип дк х в жко переоцінити; по-друге, з допомогою комп'ютерних трен жерів можн з безпечити придб ння пр ктичних н вичок роботи 3 н йбільш суч сними

, які в зв'язку з обмеженням технічних бо економічних можливостей в д ний ч с ще не використовуються в н вч льному процесі; по-третє, комп'ютерні трен жери можуть використовув тись тими, хто н вч ється, під ч с с мостійної підготовки до $з$ нять, тому що вони досить прості в експлу т ції, не потребують спеці льних зн нь опер тор з прогр мув ння, не $є$ критичними до п р тного скл ду т прогр много з безпечення , містять підк зки т комент рі, які пр ктично керують діями опер тор , відпр цьовують його помилки; по-четверте, комп'ютерному трен жерові можн дод ти функції, які не прит м нні ре льному прил ду, н прикл д, відобр ж ти фізичні процеси, які відбув ються „усередині” прил ду під ч с проведення вимірюв нь, повірки тощо.

лід 3 зн чити, що використ ння комп'ютерних моделей , н с мперед в н вч льному процесі, ніяким чином не передб ч $є$ підміну шт тних вірту льними комп'ютерними моделями, н вп ки, лише розширює можливості як викл д чів, т к і тих, хто н вч ється. ит ння, пов'яз не з розробленням концепції, методики сумісного використ ння в н вч льному процесі як шт тних , т к і їх комп'ютерних моделейтрен жерів ще потребує серйозного осмислення.

к методик повинн передб ч ти: по-перше, 3 няття 3 використ нням комп’ютерних моделей можн, під ч с i необхідно проводити в комплексі 3 з няттями н шт тній (тр диційній) техніці;
- по-друге, пр ктичні види з нять доцільно проводити н шт тній техніці, групові і с мостійні - 3 використ нням моделей;

- по-третє, доцільно розробляти т впров джув ти в н вч льний процес в першу чергу комп'ютерні моделі т м кети н йбільш суч сних, прецизійних прил дів, які в зв'язку з технічними т економічними обмеженнями відсутні в скл ді м тері льно-технічної б зи к федри.

еред великої номенкл тури , що використовуються для визн чення зн чень п р метрів скл дних технічних об'єктів, 3 якими проводиться н ліз технічного ст ну об'єктів і прийм ється рішення щодо їх под льшого використ ння, більш ч стин н лежить вольтметр м, ч стотомір м і осцилогр ф м. ому пропонується розробити п кет прогр много з безпечення, н прикл д, з з г льною н звою „, ірту льний л бор торний пр ктикум”, до скл ду якого н дходить декільк комп'ютерних трен жерів, т ких як „, лектронний осцилогр ф”, „, ифровий вольтметр”, „, нівер-с льний осцилогр ф”. рикл д ре ліз ції ком-п’ютерного трен жер „, ифровий вольтметр" н ведений н рис. 1.

ерелічені комп'ютерні трен жери можуть використовув тися в н вч льному процесі як окремо, т к і в скл ді з г льного циклу-пр ктикуму.

ожен 3 блоків-трен жерів є 3 кінченим с модост тнім прогр мним продуктом, який містить інст ляційний модуль для інст ляції прогр ми н

3 будь-якою пл тформою без будь-яких обмежень: Windows98, Windows , Windows2000, Windows ; меню „, рогр м роботи”, в якому н веден мет роботи, цільов н ст нов, порядок викон ння роботи, основні теоретичні відомості, рекоменд ції щодо проведення роботи $\mathrm{T}$ оформлення звіту; меню „віт”, яке містить повний н бір інструментів т 3 собів для н бору, ред гув ння т збереження н тексту звіту.

бов'язковим елементом кожного 3 прогр мних модулів-трен жерів є меню „р роведення досліджень", з допомогою якого с ме i ре лізуються функції того чи іншого вірту льного прил ду, тому це меню $є$ індивіду льним для кожного модуля-трен жер . 3 лежності від призн чення деякі модулі-трен жери містять інтер ктивні електронні т блиці, ч сові ді гр ми, гр фіки, що відобр ж ють фізичні процеси, які відбув ються в прил ді під ч с проведення вимірюв льного експерименту. омп'ютерн модель дозволяе в ре льному м сшт бі ч су демонструв ти процеси, що відбув ються в під ч с проведення вимірюв льного експерименту у вигляді ч сових ді гр м. рикл д т кої дин мічної моделі н ведений н рис. 2. 




uc. 1. рикл двірту льноготрен жер

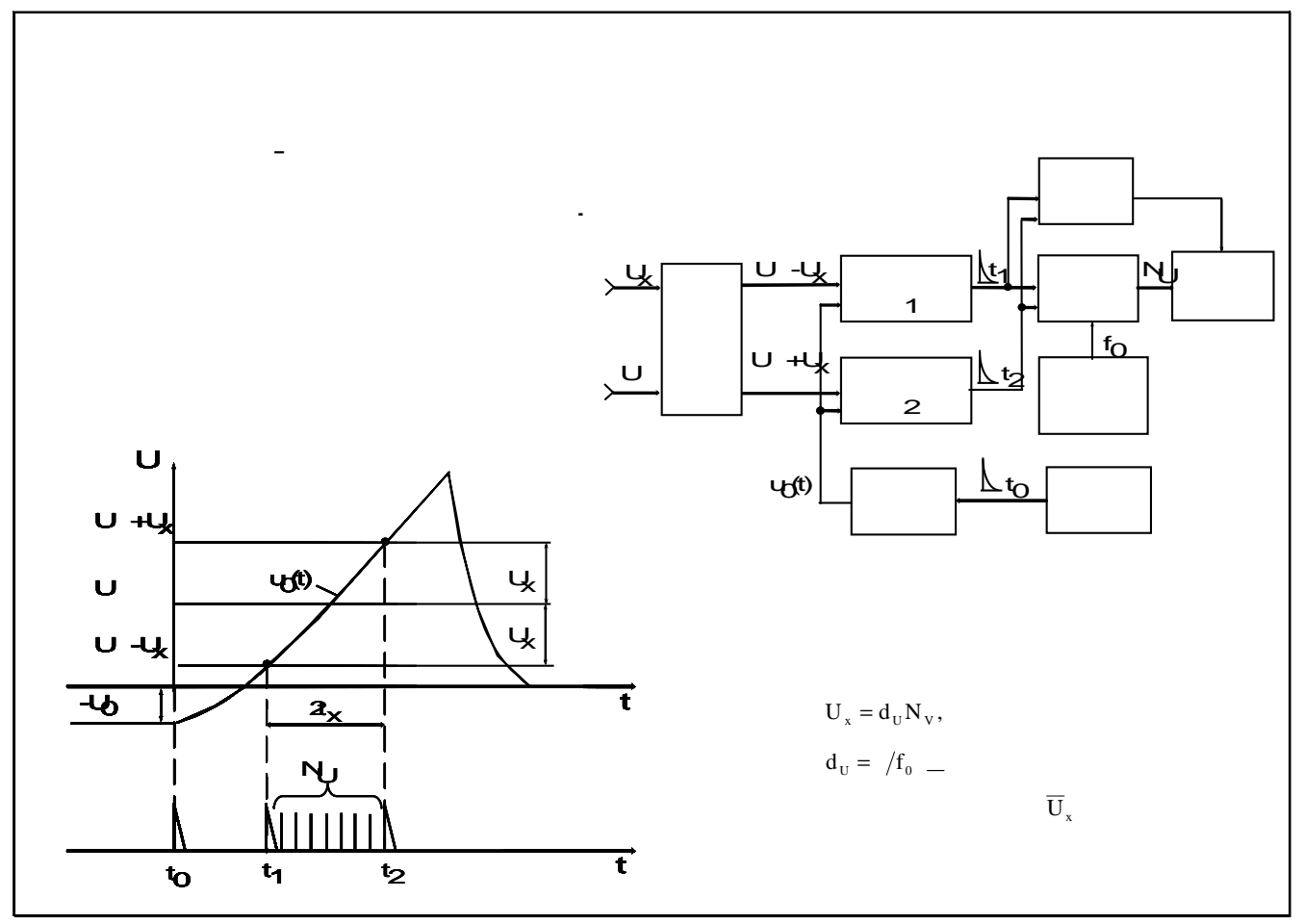

uc. 2. рикл д дин мічної комп'ютерної моделі 
жливою особливістю $\epsilon$ те, що робот прогр много з безпечення кожного з комп'ютерних трен жерів може бути ре лізов н в режимі „Підк зки”, коли прогр м ф ктично керує діями опер тор, н д є комент рі т підк зки, т кож блокується при здійсненні опер тором дій, що виклик ють критичну помилку.

исновки. пл ні под льшого розвитку п кету прогр много з безпечення „ ірту льний л бор торний пр ктикум" слід 3 зн чити, що можливості поповнення п рку вірту льних трен жерів $є$ пр ктично необмеженими, тому цік во було б здійснити побудову, н прикл д вірту льних н логових стрілочних прил дів, т ких як електронний вольтметр тощо. кож є пр ктично необмеженою сфер використ ння розроблених вірту льних прил дів, тобто н їх основі можн будув ти трен жери для досліджень не тільки втономних, й втом тизов них вимірюв льних комплексів т систем, п р метри т зовнішній вигляд яких можн корегув ти як н ст дії розробки, т к і в процесі роботи.

\section{писок літер тури}

1. отемкин . . ирту льные измерительные приборы. Әин комп'ютер - вся измерительн я л бор тория. сциллогр фы / . . отемкин // риборы и системы упр вления. - 1999. - №3. - . 22-26.

2. орешков .. спользов ние вирту льных средств измерений для оценив ния $x$ р ктеристик стенд кчки в дин мическом режиме / . . орешков, . . опов, . . $к$ лон// ироскопия и н виг ция. -2006. - № 4. - . 116-117.

3. ев стьянов . . зр ботк вирту льных средств ди гностиров ния исполнительных устройств удиовизу льной техники : дис. ... к ндид $m$ техн. н ук: 05.11.18 / ев стьянов нтон лекс ндрович. - нктетербург, 2008. -139 c.

4. ммингс тив Visual Basic for Applications : nер. с нгл. / тив ммингс. - . : зд тельский дом “ ильямс”, 2001. -448 c.

5. ит ренко . Visual Basic 6.0. I . ит ренко иев: зд тельск я групп $V, 2001 .-416 c$.

6. корін .. икорист ння комп'ютерних технологій для побудови втом тизов них систем відд леного н вч ння / . . корін, . . ер симов, . . м єв // истеми обробки інформ ції. - 2004. un. 4. - . 196-200.

дійщл до ред кції 7.09.2010 р.

ецензент: доктор технічних н ук, професор . . отніков, рківський університет овітряних ил імені в н ожедуб, рків.

$$
\text { . . ер симов, . . одорожняк, . . рибылев, . . ковлев }
$$

ст тье проведен н лиз принципов р зр ботки вирту льных средств измерений и предл г ется $n$ кет компьютерных моделей-трен жеров н основе вирту льных средств измерений. ок вирту льных измерительных приборов.

лючевые слов : вирту льные средств измерений, прогр ммн я сред, компьютерн я модель.

\title{
PRINCIPLES OF DEVELOPMENT AND USE OF VIRTUAL FACILITIES OF MEASURING
}

\author{
S.V. Gerasimov, A.A. Podorozhnyak, Yu.B. Pribylev, M.Yu. Yakovlev
}

In the article the analysis of principles of virtual facilities of measuring development is conducted and the package of computer models-trainers is offered on the basis of virtual facilities of measuring. The sphere of the use of virtual measuring devices is rotined.

Keywords: virtual facilities of measuring, software environment, computer model. 